DOI: https:// 10.15407/kvt195.01.082

UDC 602.9:611.018

CHERNYSHOVA T.A., physician, e-mail: tetyana.che@gmail.com Aviation Medical Center of the National Aviation University, Komarova av., 1, Kyiv, 03058, Ukraine

\title{
CRITERIA AND METHOD FOR DETECTION OF CIRCULATING TUMOR CELLS
}

Introduction. Modern advances in science and technology have substantially expanded the possibilities for detecting malignant neoplasms. A great number of methods for the detection and allocation of circulating tumor cells clearly indicates the interest of researchers to this problem.

The purpose of the work is to form a complex of criteria for tumor malignancy evaluation and to improve the method of detecting circulating tumor cells in human blood.

Results. The proposed method for determining circulating tumor cells, which is an improvement of ISET technology, combines two stages. At the first stage the improvement is in adding two additional polycarbonate filters with 5 and 3 micron diameter pores, and providing a mode of $100 \%$ sealing of the chamber with hemolysis, and constant pressure throughout the filtration process. At the second stage, we carried out the determination of malignancy degree of the isolated cells using the developed set of criteria. The use of the developed method in the automated system for the analysis of digital microscopic images of circulating tumor cells provides the detection and calculation of characteristic features for assigning an object to a certain class of malignancy and the creation of scanned images database with recorded existing cells or their entities, as well as the final verification of the results of tumor malignancy evaluation for template masks of circulating tumour cells and benign tumor cells.

Conclusions. The application of the proposed method for the detection of circulating tumor cells allows detecting smaller cells than in case of using traditional methods, ensures their integrity and intactness.

Keywords: circulating tumor cells, criteria for evaluation of tumormalignancy, method of determining circulating tumor cells in human blood.

\section{INTRODUCTION}

Modern achievements in science and technology have substantially expanded the possibilities for detecting malignant neoplasms. However, despite the wide arsenal of auxiliary research methods, the physician often has significant difficulties in making the accurate diagnosis, which is ultimately reflected in the treatment. The problem of detecting and recognizing the circulating tumor cells (hereinafter - CTC) has become relevant in the last few decades because it is important for the treatment of a patient for

(C) CHERNYSHOVA T.A., 2019 
a number of reasons [1-2]. At the beginning of the primary tumor development, the detecting of CTC allows making an early diagnosis. The amount of CTC is reduced in response to treatment, that is why monitoring the $\mathrm{CTC}$ amount let us analyze the effectiveness of a particular treatment regimen [3]. At the same time, the change in the CTC amount can be used as a means for tracking relapse in patients with no signs of disease in case of adjuvant chemotherapy [4].

There are a great number of methods for CTC detecting and allocating which clearly point to researchers interest to this problem. Despite the diversity of methods, the findings of patient screening and determining the clinical prognosis of existing CTC is always associated with a negative prognosis for survival.

\section{THE PROBLEM STATEMENT}

Now, the tremendous efforts of doctors and scientists are focused on optimizing the methodological, informational and technical aspects of the CTC detection and evaluation for various types of cancer and, above all, breast cancer, prostate cancer, skin cancer (melanoma), colorectal cancer and micellar lung cancer.

These efforts are mainly aimed at reducing the qualitative and quantitative errors in the CTC calculation, as well as minimizing the CTC loss caused by excessive blood transfusion during treatment. Most of the available approaches for capturing CTC are based on the differences in these cells from normal cellular blood components by physical (size, density, potential difference) and molecular (e.g., surface expression) characteristics.

Optical method for estimating the CTC amount in a blood sample is based on automatic digital microscopy. To reduce the time of scanning large areas of cytological preparations, the technology of massive optical fiber scanning is proposed, which can scan 500 times bigger area than automatic digital microscopy technology without degrading the sensitivity of this process for a shorter period of time $[5,6]$. There are a number of technologies and systems based on the methods of immunofluorescence, immunomagnetic division, flow cytometry and other immunomagnetic methods that allow the tumor cells isolation by means of magnetic field, using the ability of these cells to interact with antibodies against CTC markers with conjugated magnetic particles [7-14]. But there is no analytical consideration of using such technologies for the purpose of early non-invasive detection of cancer.

The CTC selection was also performed morphologically. One of the directions of such methods development is the detection of the studied CTC by size using microfilters $[15,16]$. Although these methods allow a significant increase in resolution, cells are often deformed and destroyed during detection [16, 17], which stimulates to pay special attention to prevent such destruction or to increase the integrity of the detected cellular fractions $[15,17]$.

One of the most informative markers for the tumor process progression is the CTC in blood, the increased number of which can lead to a more thorough examination of patients in the "asymptomatic period" [18, 19]. According to the results of randomized trials conducted in several clinical and research centers, authors determined the role of the CTC level increasing in the development of tumor progression in breast cancer, prostate and colorectal cancer [20]. In the studied patients, elevated levels of CTC (from 3 to 400 cells per specimen) were detected in $75 \%$ of cases. 
Table 1. Dependence of the amount of CTC in peripheral blood on the degree of the tumor differentiation [20]

\begin{tabular}{|l|c|c|}
\hline Degree of the tumor differentiation & $\begin{array}{c}\text { Number of patients, } \\
\text { absolute numbers (\%) } \\
\text { with CTC }>\mathbf{3 n}=\mathbf{3 0}\end{array}$ & $\begin{array}{c}\text { Number of patients, } \\
\text { absolute numbers (\%) } \\
\text { with CTC }<\mathbf{3 n}=\mathbf{1 0}\end{array}$ \\
\hline Well differentiated adenocarcinoma & $5(12,5 \%)$ & $3(7,5 \%)$ \\
\hline $\begin{array}{l}\text { Moderately differentiated adenocar- } \\
\text { cinoma }\end{array}$ & $9(25 \%)$ & $5(10 \%)$ \\
\hline $\begin{array}{l}\text { Poorly differentiated adenocarci- } \\
\text { noma }\end{array}$ & $16(42,5 \%)^{*}$ & $2(2,5 \%)^{*}$ \\
\hline
\end{tabular}

Note: * - a statistically significant difference in the detection of patients with CTC $>3$ and $<3$ with poorly differentiated adenocarcinoma, $\mathrm{p}=0.0235$.

According to the standardized requirements for the CTC study, the sample is considered to be positive for any number of CTC which exceeds 3 cells. The degree of tumor differentiation affects the amount of CTC in peripheral blood (Table 1).

Retrospective analysis showed that early relapses and metastases (up to 24 months) developed more frequently in patients with the CTC level of more than 3 cells.

Due to the analysis of numerous studies in this area, the presence of circulating tumor cells in the blood indicates the acquisition of fundamentally new qualities of tumor such as invasiveness and the ability to metastasize. Undoubtedly, CTCs are not the only key to understanding the biology of metastasis, but also a prognostic and predictive newcomer oncomarker that reflects the effectiveness of antitumor treatment. One of the most important issues for improving the methods of determining the CTC is to ensure the separation of integral and intact CTCs with further evaluation and determination of effective criteria for assigning selected cells to malignant neoplasms.

The purpose of the work is to form a complex of criteria for tumor malignancy evaluation and to improve the method of detecting circulating tumor cells in human blood.

\section{COMPLEX OF CRITERIA FOR DETERMINING THE MALIGNANCY OF CIRCULATING TUMOR CELLS}

The principle of forming a set of criteria is a combination of the sequential definition of two groups of criteria and the expansion of the criterion space to 5 micron and 3 micron cells.

The $1^{\text {st }}$ group of criteria. By the ISET method [21-24], the definition of tumor malignancy is carried out according to five criterion characteristics: the variation of the nuclei size of isolated cells, anisonucleosis - $\mathrm{C} 1$; exceeding the size of the cell nucleus for a triple calibrated pore size - $\mathrm{C} 2$; presence of abnormalities of the nucleus (shape, contours, area) - C3; the value of nuclear-cytoplasmic ratio (NCR), that is, the ratio of the area of the nucleus $(\mathrm{Sn})$ to the area of the cytoplasm of the cell (Sc) - C4; the presence of cellular complexes-C5 (Table 2). 
Table 2. Criteria for tumor malignancy according to ISET in our version

\begin{tabular}{|c|c|c|c|}
\hline & \multicolumn{2}{|c|}{ Criterion characteristics } & Criterion \\
\hline 1 & \multicolumn{2}{|c|}{ Anioniculosis is the ratio of different sizes of cell nuclei } & $\mathrm{C}_{1}>0,5$ \\
\hline \multirow{2}{*}{2} & \multirow{2}{*}{$\begin{array}{c}\text { Nuscleus } \\
\text { size }\end{array}$} & - for $8 \mu \mathrm{m}$ pore size & $\mathrm{C}_{2}>24 \mu \mathrm{m}$ \\
\cline { 3 - 4 } & & - for $5 \mu \mathrm{m}$ pore size & $\mathrm{C}_{2}>15 \mu \mathrm{m}$ \\
\hline 3 & \multicolumn{2}{|c|}{ Abnormality of the nucleus (shape, contours, squares) } & $\mathrm{C}_{2}>7,5$ \\
\hline 4 & \multicolumn{2}{|r|}{ Nuclear-cytoplasmic ratio } & present \\
\hline 5 & \multicolumn{2}{|r|}{ Cellular complexes } & high \\
\hline
\end{tabular}

Table 3. Criteria for the degree of the tumor malignancy according to P. Scarft, H. Bloom, W. Richardson [25]

\begin{tabular}{|c|c|c|}
\hline Index & Criterion & Points \\
\hline \multirow{3}{*}{$\begin{array}{c}\text { Formation of tubular and flow } \\
\text { structures }\end{array}$} & $\mathrm{R}_{1}>75 \%$ & 1 \\
\hline & $75 \%>\mathrm{R}_{1}>10 \%$ & 2 \\
\hline & $\mathrm{R}_{1}<10 \%$ & 3 \\
\hline \multirow{3}{*}{ The number of mitoses } & $\mathrm{R}_{2}<10 \%$ & 1 \\
\hline & $20 \%>\mathrm{R}_{2}>10 \%$ & 2 \\
\hline & $\mathrm{R}_{2}>20 \%$ & 3 \\
\hline \multirow{3}{*}{ Cellular polymorphism } & $\begin{array}{c}\text { cells of the same size and shape, shallow, } \\
\text { with dispersed distribution of chromatin, } \\
\text { without nucleoli }\end{array}$ & 1 \\
\hline & $\begin{array}{c}\text { small polymorphism of the nuclei and some } \\
\text { aggregation of cells }\end{array}$ & 2 \\
\hline & $\begin{array}{c}\text { The nuclei are large, of different shapes, } \\
\text { with one or more nucleoli and coarse chro- } \\
\text { matin }\end{array}$ & 3 \\
\hline
\end{tabular}

A detected CTC is considered to be malignant if it meets 4 of the above 5 criteria.

The $2^{\text {nd }}$ group of criteria. To improve the results reliability in the case of some forms of cancer and, when determining the degree of tumor malignancy becomes a complex and time-consuming process, we additionally use the modified scheme of P. Scarft, H. Bloom, W. Richardson [25]. It reveals 3 groups of malignancy according to such characteristics as formation of tubular and flow-like structures (R1), number of mitoses (R2), cellular polymorphism (R3) (Table 3).

The degree of tumour malignancy (hereinafter - DTM) is determined by the sum of points according to three characteristics:

$$
\mathrm{DTM}=\mathrm{R} 1+\mathrm{R} 2+\mathrm{R} 2
$$

Classification of the degree of malignancy:

I (low) - 3-5 points;

II (moderate) - 6-7 points;

III (high) $-8-9$ points.

Thus, the developed set of criteria for the DTM is based on a combination of sequential determination on two criteria scales: 1) ISET with the proposed expansion of the criterion space on the cell range (5 microns and 3 microns), and 2) the modified scheme of P. Scarft, H. Bloom, W. Richardson [25]. 


\section{DETECTION AND EVALUATION OF MALIGNANCY OF CIRCULATING TUMOR CELLS}

Using the Isolation by Size of Tumor Cells Isolation Method. The basic method of our study is the Isolation by Size of Tumor Cells (ISET ${ }^{\circledR)}$ ) method $[21,22,26]$. This innovative, proprietary method allows for the loss of isolation from CTCs (as well as circulating tumor microembolism or clusters from several CTCs), provided that their integrity is maintained and analyzed by various methods, including blood cytopathology $[27,28]$. In addition, ISET ${ }^{\circledR}$ Cytopathology for blood is the most sensitive method for CTC diagnosis, which is an early sign of cancer invasion. Long before the metastases, the CTCs flow in the bloodstream and can be diagnosed using this technology. Thus, oncologists receive additional information about the invasive potential of cancer which helps to stop cancer invasion before the formation of metastases [28].

The ISET system is based on the classic cytopatological criteria: tumor cells, originating from various solid tumors (more than 16 microns in diameter) are larger than blood cells. The ISET technology allows quick processing of a blood sample on a filter without using antibodies and isolated unharmed fixed tumor cells up to $8.5 \mu \mathrm{m}$ in diameter using a standard membrane with a nominal pore size of $8 \mu \mathrm{m}[29]$.

Improvement of the method. The question of the hypothetical loss of "small" CTC through pores of 8 microns is really important. We emphasize that to this day the minimum size of the CTC diagnosed with different methods was more than 8 microns.

Improvement of the basic method is carried out due to:

- installation of two additional polycarbonate filters with 5 and 3 microns diameter pores,

- providing a mode of $100 \%$ sealing of the camera with hemolysis and constant pressure throughout the filtration process,

- use of the developed set of criteria,

- application of the proposed method for processing microscopic CTC images, which enables to detect CTC of any size, integral and intact.

The research was carried out on an experimental installation, which was developed by an author team of scientists from Vinnitsa and Mariupol [30]. Differences in the methods, approaches, information provision and hardware and software used provided practically $100 \%$ sealing of the cylinder and the uniform distribution of pressure on CTC during their filtration, as well as the exclusion of the influence of the subjective factor in the process of creating pressure on the sample.

The proposed method involves two stages which are two blocks of research.

The first stage is the allocation of integral itact CTC. The principle of this stage involves filtering of patients' blood through a polycarbonate membrane with specified pore sizes using the ISET system [22] with the inclusion of two additional polycarbonate filters with pores diameter of 5 and 3 microns. Thus, the filtration module consists of 10 membranes; each of them allows to simultaneously filter $1 \mathrm{ml}$ of blood (10 $\mathrm{ml}$ of blood) through 10 membranes with $8 \mu \mathrm{m}$ diameter pores, then 10 membranes with $5 \mu \mathrm{m}$ diameter pores and 10 membranes with $3 \mu \mathrm{m}$ diameter pores.

At the first, preparatory step, a blood sample of a patient is prepared for the study. A blood sample of $10 \mathrm{ml}$ (peripheral or venous) obtained from the patient was mixed to prepare hemolysis with $100 \mathrm{ml}$ of distilled water. The prepared sam- 
ple was mixed in a haematological scanner-analyzer such as Vision Hema@ Assist. Next, we performed citation tests - the division of the blood sample into plasma, red blood cells, lymphocytes, platelets with selective removal of pathologically altered cells using a centrifuge-generator of the scanner. The degree of sedimentation of the particles in the solution (precipitation or expulsion, depending on the density of the solution) was estimated by the sedimentation factor (S):

$$
S=\frac{M(1-\bar{V} \rho)}{f},
$$

where $M$ - is the molecular weight of the particle; $f$ - is a form of the particle (coefficient of friction); $\bar{V}$ - is the partial volume of particle; $\rho-$ is the solution density.

The preparatory step ended with the procedure of disaggregation of cells and lyse of red blood cells (within 20 minutes). The general view of the membrane with the study areas is presented in Fig. 1.

In subsequent steps, the membranes were dried, washed with $96 \%$ alcohol or phosphate-basic buffer. We performed cytomorphological, cytoimmunological and molecular analysis on the slots of the received membranes. The painting of slots was carried out using the Romanovskii-Giemsa methods or the modified May-Grunwald-Giemsa method [30].

After filtration and appropriate treatment of the membrane, the doctor receives a sample of the cell preparation.

The study process involved the step-by-step obtaining of microscopic images of the CTC, where we can see the lymphocyte (1), the CTC (2), the nuclear-free CTC, i.e. the CTC death due to the courses of therapy or the body's immune response (3), and filter pores (4) (Fig. 2).

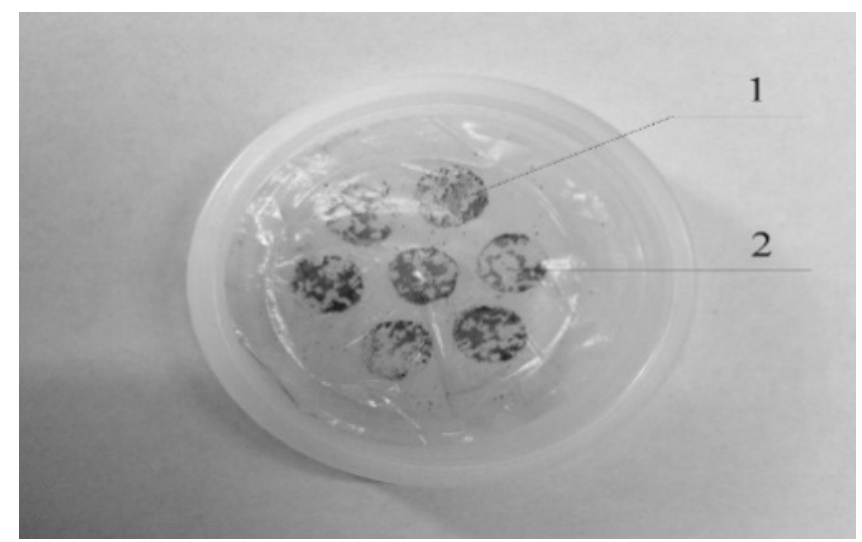

Fig. 1. The general view of the membrane with the study areas (1 - the site was treated with Cytokeratin clon $\mathrm{AE} / 1 \mathrm{AE} / 3$;

2 - the site was treated according to Romanovskii-Giemsa) 


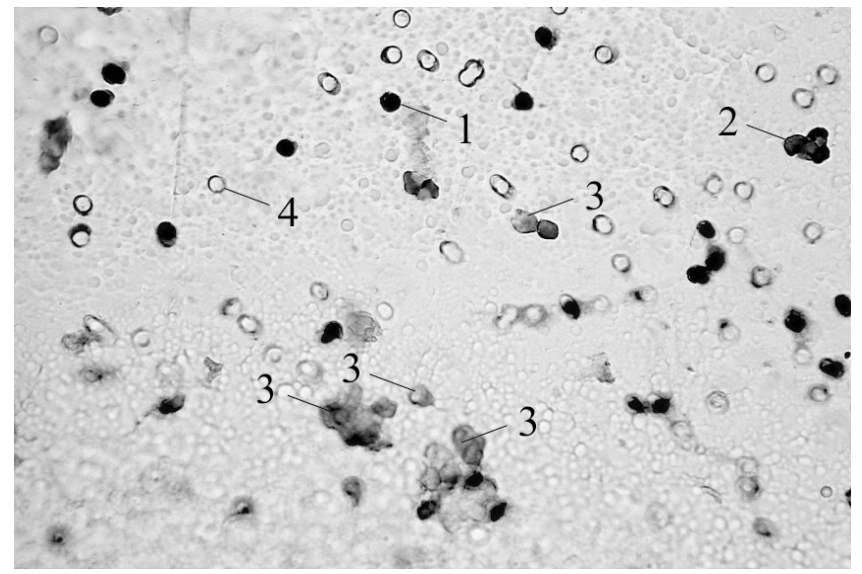

Fig. 2. Results of the CTC detection

Thus, the first stage of the advanced method of the detection and allocation of integral intact circulating tumor cells comprised the following steps: step 1 preparation of a patient's blood sample for research; step 2 - the blood sample division into plasma and uniform elements with the help of a centrifuge-generator of the scanner; step 3 - sedimentation of particles in solution (sedimentating) or (expulsion) and determination of degree of sedimentation.

The second stage II - confirmation of the tumor malignancy. This is the key stage of the method because it is precisely at this stage we determine whether there are CTCs in the patient's blood. At the first steps of this stage, confirmation of tumor malignancy is carried out using the developed set of criteria described above. For this purpose, the criteria of the first group are sequentially determined. If there are at least 4 criteria out of 5 in this group, the primary conclusion about the tumor malignancy is drawn.

As a result of empirical and practical laboratory studies using the ISET method, we found out that the NCR of two or even three cancer cells might have practically the same meaning for essentially different sizes of CTCs and their nuclei. To avoid the ambiguity of the results integration, we proposed to switch to the absolute sizes of cells and their nuclei and introduce a blood contamination index, which was defined as the amount of CTCs detection in $1 \mathrm{ml}$ (or $10 \mathrm{ml}$ ) of blood.

For the final examination of the results of the tumor malignancy evaluation, we compared them with the CTC template masks and benign tumor cells. The algorithm for evaluation of tumor malignancy is presented in Fig. 3.

Automated CTC image formation. The developed method is the basis of the automated system for the CTC digital images analysis [31, 32]. In order to automate the analysis of a biomedical image, in particular blood cells, in the first stage imaging procedures are performed that are associated with suppressing the distorting factors of the image (filtering obstacles, eliminating lighting inequalities, etc.). 


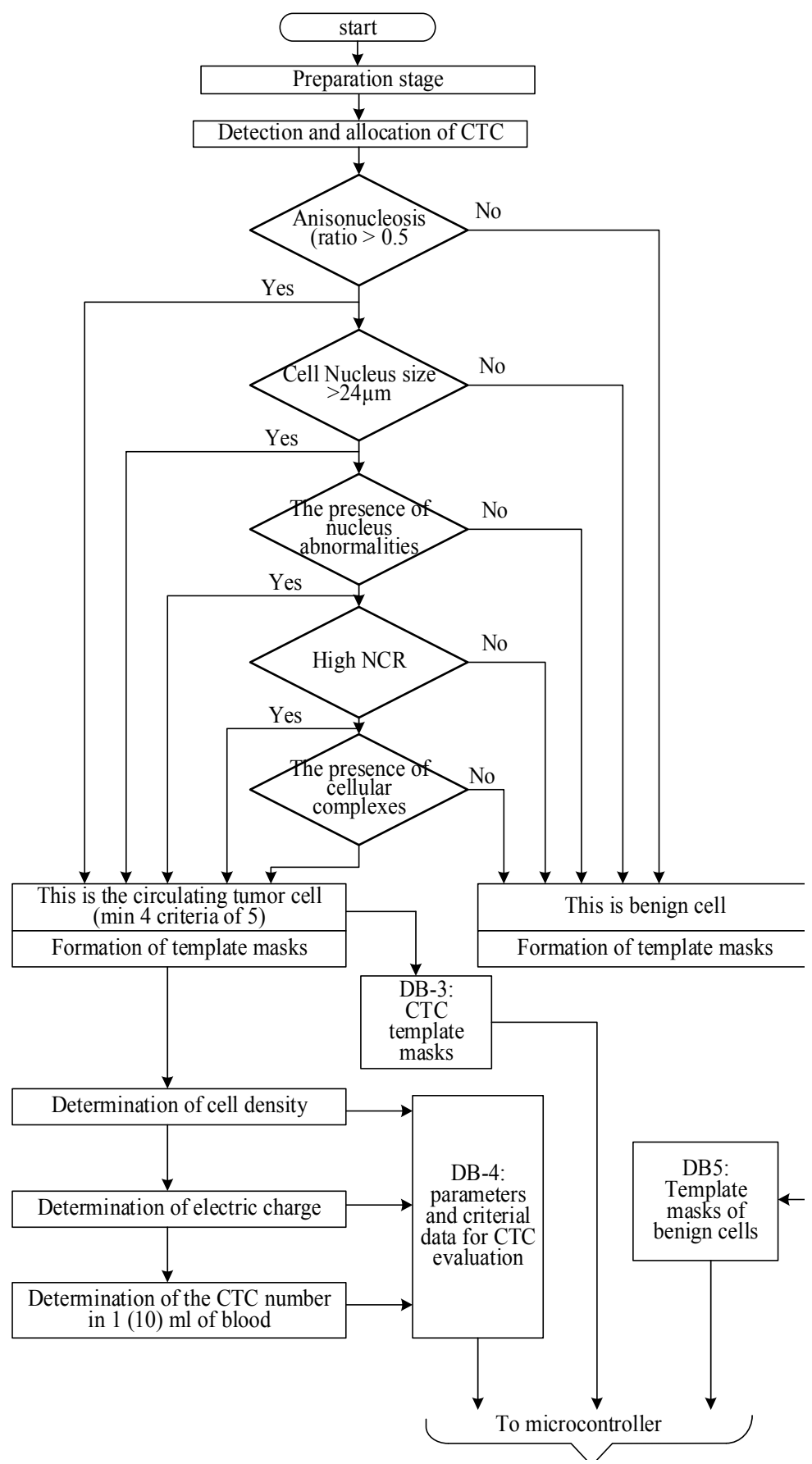

Fig 3. An algorithm for determining the tumor malignancy

Next, the process of scanning images of cells located on the surface of polycarbonate membranes is carried out. The size of the image which is scanned in one step of the microscope's subject table should not exceed the microscope monocular diameter. At the beginning of the process of scanning the $8 \mu \mathrm{m}$ pores 
membrane, there are images (scans) that lack any cells or their formation regardless their origin (malignant or benign) and they are excluded from further processing and analysis. Detected scans with existing cells or their entities are recorded and stored in the appropriate database (DB 1). After completion of the 8 $\mu \mathrm{m}$ pores membrane scanning, all of the above procedures are performed with the $5 \mu \mathrm{m}$ pores membrane (DB 2), and then with the $3 \mu \mathrm{m}$ pores membrane (DB 3 ). The databases with CTC images scanning of various sizes provide a qualitative and flexible classification of types of cancer and create the basis for oncological patients' registration with their CTCs.

The further steps of this stage deal with the identification of disseminated tumor cells and CTCs. Bringing the image to the required quality is based on changing the contrast of the image, changing the narrowed or shifted range of pixel brightness of the image, and its uneven filling, etc. [33].

Processing of histological sections images containing cellular structures is a set of solutions of the following tasks: evaluation of visual quality of digital images; linear image filtering; threshold processing; median filtration. Figure 4 shows the CTC image after calculating the brightness gradient (Fig. 4a) and the CTC image after filling in the inner regions (Fig. 4b).

At the description stage we perform the definition and calculation of feature characteristics of the object which are the basis for the third step connected with the assignment of an object to a particular class. The description stage is the main stage out of these three. The choice of signs and their informativity (the possibility of attributing an object to a particular class due to its characteristics) are crucial in determining the result of detection.

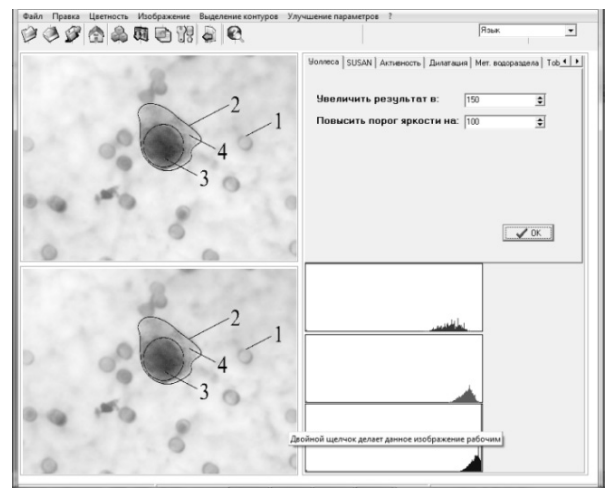

a

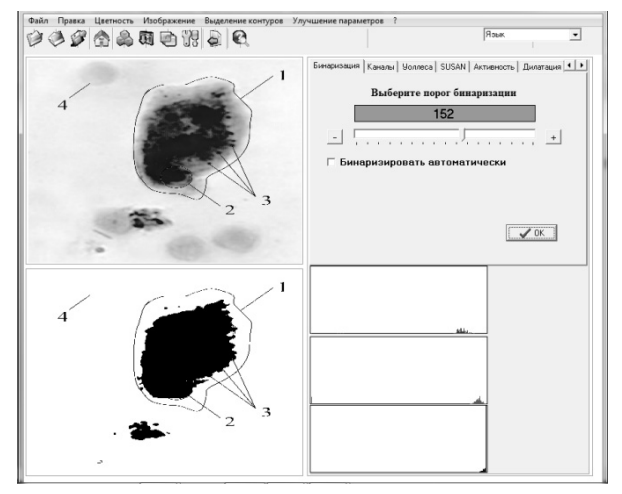

b

Fig 4. CTC image after calculating the brightness gradient (a) and the CTC image after filling in the inner regions (b) 


\section{RESEARCH USING THE PROPOSED METHOD}

We performed the analysis of peripheral blood samples in patients with primary diagnosis of colon, breast, lungs, prostate and skin cancer. Blood samples were provided by oncology centers and clinics in Mariupol, Vinnitsa and Ternopil, and were encoded by the name of the city and the serial number of the sample. The studies were conducted at the specified clinical bases simultaneously with other methods because of the need to adhere to certain requirements, such as: blood sampling should be $10 \mathrm{ml}$ in anticoagulant test tubes EDTA (blood from the peripheral vein); storage time before the analysis beginning should be no more than 90 minutes; storage temperature should be $4{ }^{\circ} \mathrm{C}$; blood dilution in the ratio of 1:10 (up to $100 \mathrm{ml}$ ) shoul be performed with a proprietary buffer solution (sanolin, paraformaldehyde, EDTA, pour albumin), which was used for red blood cells lysis [34, 35].

The obtained results analysis showed that the use of the developed method enabled to determine false-positive diagnoses in $6.2-8.9 \%$ of cases.

We also found out that in patients with colorectal cancer, CTC in the blood was more often detected in the case of low-differentiated tumors. In patients with breast cancer, the most cases of CTC detection fell on the third stage of the disease ( $85 \%$ or 12 patients), other $15 \%$ were on the second stage. It should be noted that most patients with prostate cancer with detected CTC had metastases in the liver and bones. The obtained data for small-cell lung cancer did not contradict the literary data indicating a decrease in the CTC incidence in non-small cell lung cancer than in the case of small-cell lung cancer. A similar conclusion can be made about skin cancer. That is, the obtained results correlate with a high degree of statistic significance $(>95 \%)$ with the data suggested by the literature.

We sent the obtained microscopic CTC images and diagnosis made according to them with unchanged codes to the appropriate clinics and conducted a final discussion of these results. After a full-format analysis, we performed the correction of range and treatment tactics in cases where it was necessary.

\section{CONCIUSIONS}

The proposed method for determining circulating tumor cells, which is an improvement of ISET technology, combines two stages. At the first stage we improved the ISET technology by adding two additional polycarbonate filters with 5 and 3 micron diameter pores, and providing a mode of $100 \%$ sealing of the chamber with hemolysis, and constant pressure throughout the filtration process. At the second stage, we carried out the DTM of the isolated cells using the developed set of criteria. The application of the proposed method for processing microscopic CTC images allows to detect smaller CTCs than in the case of using traditional methods, and to ensure their integrity and intactness.

The use of the developed method in the automated system for the digital images analysis of circulating tumor cells provides the detection and calculation of characteristic features for assigning an object to a certain class of malignancy. Scanning of images of the researched cells is carried out and detected scans with existing cells or their entities are sequentially recorded and stored in the appropriate database. For the final examination of the results of the tumor malignancy evaluation, comparisons are made with the CTC template masks and benign tumor cells. 
Clinical and experimental study using the proposed method for CTC detecting revealed an opportunity to clarify the diagnosis and identify false positive diagnoses. The study proved that colorectal cancer was more often diagnosed with low-differentiated tumors and, the highest breast cancer incidence occured at the third stage of the disease. The effectiveness of the proposed method was also confirmed in patients with other types of cancer.

\section{REFERENCES}

1. Krivacic R.. Ladanyi A., Curry D., Hsieh H., Kuhn P., Bergsrud D., Kepros J. A rare-cell detector for cancer. Proceedings of the National Academy of Sciences of the United States of America. 2004. V. 101, N 29. P. 10501-10504.

2. Harouaka R., Kang Z., Zheng S.Y., Cao L. Circulating tumor cells: advances in isolation and analysis, and challenges for clinical applications. Pharmacol Ther. 2014. Vol. 141. P. 209-221.

3. Tewes M., Aktas B., Welt A., Mueller S., Hauch S., Kimmig R., Kasimir-Bauer S. Molecular profiling and predictive value of circulating tumor cells in patients with metastatic breast cancer: an option for monitoring response to breast cancer related therapies. Breast cancer research and treatment. 2009. Vol. 115, N 3. P. 581-590.

4. Danila D.C., Heller G., Gignac G.A. et al. Circulating tumor cell number and prognosis in progressive castration-resistant prostate cancer. Clin Cancer Res. 2007. Vol. 13(23). P. 7053-7058.

5. Krivacic R.. Ladanyi A., Curry D., Hsieh H., Kuhn P., Bergsrud D., Kepros J. A rarecell detector for cancer. Proceedings of the National Academy of Sciences of the United States of America. 2004. Vol. 101, N 29. P. 10501-10504.

6. Ntouroupi T., Ashraf S., McGregor S., Turney B., Seppo A., Kim Y., Wang X. Detection of circulating tumour cells in peripheral blood with an automated scanning fluorescence microscope. British journal of cancer. 2008. Vol. 99, N 5. P. 789-795.

7. Bauer K., de la Torre-Bueno J., Diel I., Hawes D., Decker W., Priddy C., Bossy B. Reliable and sensitive analysis of occult bone marrow metastases using automated cellular imaging. Clinical cancer research: an official journal of the American Association for Cancer Research. 2000. Vol. 6, N 9. P. 3552-3559.

8. Kagan M., Howard D., Bendele T., Mayes J., Silvia J., Repollet M., Doyle J. A Sample Preparation and Analysis System for Identification of Circulating Tumor Cells. Journal of Clinical Ligand Assay. 2002. Vol. 25, N 1. P. 104-110.

9. Andreopoulou E., Yang L.-Y., Rangel K., Reuben J., Hsu L., Krishnamurthy S., Valero V. Comparison of assay methods for detection of circulating tumor cells in metastatic breast cancer: AdnaGen AdnaTest BreastCancer Select. Detect ${ }^{\mathrm{TM}}$ versus Yeridex CellSearch $^{\mathrm{TM}}$ system. Int. journal of cancer. 2012. Vol. 130, N 7. P. 1590-1597.

10 Nezos A., Pissimisis N., Lembessis P., Sourla A., Dimopoulos P., Dimopoulos T., Tzelepis K. Detection of circulating tumor cells in bladder cancer patients. Cancer treatment reviews. 2009. V. 35, N 3. P. 272-279.

11. Tewes M., Aktas B., Welt A., Mueller S., Hauch S., Kimmig R., Kasimir-Bauer S. Molecular profiling and predictive value of circulating tumor cells in patients with metastatic breast cancer: an option for monitoring response to breast cancer related therapies. Breast cancer research and treatment. 2009. V. 115, N 3. P. 581-590.

12. Ignatiadis M, Lee M, Jeffrey SS. Circulating Tumor Cells and Circulating Tumor DNA: Challenges and Opportunities on the Path to Clinical Utility. Clin Cancer Res. 2015. No 21(21) P. 4786-800.

13. Alix-Panabieres $\mathrm{C}$, Pantel K. Technologies for detection of circulating tumor cells: facts and vision. Lab Chip. 2014. No 14(1) P. 57-62.

14. Ferreira M.M, Ramani V.C, Jeffrey S.S. Circulating tumor cell technologies. Mol Oncol. 2016. 10(3) P. 374-94.

15. Gertler R., Rosenberg R., Fuehrer K., Dahm M., Nekarda H., Siewert J. Detection of circulating tumor cells in blood using an optimized density gradient centrifugation. 
Recent results in cancer research. Fortschritte der Krebsforschung. Progres dans les recherches sur le cancer. 2003. Vol. 162. P. 149-155.

16. Tan S., Yobas L., Lee G., Ong C, Lira C. Microdevice for the isolation and enumeration of cancer cells from blood. Biomedical microdevices. 2009. V. 11, N 4. P. 883-892.

17. Tan S., Yobas L., Lee G., Ong C, Lira C. Microdevice for the isolation and enumeration of cancer cells from blood. Biomedical microdevices. 2009. V. 11, N 4. P. 883-892.

18. Kovalev A.A, Grudinskaya T.V., Kuznetsov T.P., Kovalev K.A. Heterogeneity of circulating tumor cells. Oncology. 2012. V.4. No. 2 12.12-12.(in Russian)

19. Pavlov S.V, Kozhemyako V.P, Burdenyuk I.I. Rami Rebhi Hamdi. Optical and electronic technologies for the analysis of biomedical images. Vinnitsa: VNTU, 2011. $166 \mathrm{p}$. (in Ukranian)

20. Nepomnyaschaya E.I., Kit O.I., Nistratova O.V., Novikova I.A. and others. Circulating tumor cells and some morpho-immuno-histochemical indices at colorectal cancer. Modern problems of science and education. 2016. No. 2. (in Russian)

21. G. Vona, C. Béroud, A. Benachi, A. Quenette, J.P. Bonnefont, Y. Dumez, B. Lacour, P. Paterlini-Bréchot. Enrichment and genetic analyses of fetal cells circulating in the maternal blood by the ISET technique and single cell microdissection: a non-invasive tool for early prenatal diagnosis. Am. J. Pathol. 2002. No 160. P. 51-58.

22. Ismayilova G., Laget S., Paterlini-Brechot P. Diagnosis of circulating tumor cells using ISET technology and their molecular characteristics for fluid biopsy. URL: https://cyberleninka.ru/article/n/diagnostika-tsirkuliruyuschih-opuholevyh-kletok-spomoschyu-tehnologii-iset-i-ih-molekulyarnaya-harakteristika-dlya-zhidkostnoy. (Last accessed: 08.12.2018)

23. Ledov V.K., Skrinnikova MA, Popova O.P. Isolation of Circulating Tumor Cells by Isolated Size (ISET) (overview). Voprosy Oncologii, 2014. №60 (5). P.548-552. (in Russian)

24. Baikhenko A.K, Shaimardinova G. M., Popova N.V., Zhusinova B.T., Ismayilova G.N. Circulating Cancer Cells: Molecular Characteristics and Monitoring of Cancer Treatment. Clinical Medicine of Kazakhstan. 2013. Vol. 4 №30. (in Russian)

25. Volchenko N.N. Cytological diagnostics of tumors of the mammary gland. Mammology, 2006, No. 1, P. 35-39. (in Russian)

26. Paterlini-Bréchot $\mathrm{P}$, Benali-Furet NL. Circulating tumor cells (CTC) detection : Clinical impact and future directions. Cancer Letter. 2007. No 253. P. 180-204.

27. Zubtsov D.A., Zubtsova J.I., Lavrov A.V., Legchenko E.V. et al. Circulating tumor cells (CAC) in breast cancer: prognostic significance and methods of excretion. Trudy MFTI. 2012. Volume 4. No. 3. P. 18-26. (in Russian)

28. Chimitov A.A.,.Ryantsantsev N.V, Dambayev G.T., Khitricheev V.E. and others. Filtration of venous blood of boluses with the aim of cytological diagnostics of malignant neoplasms. Bulleten VSNI SO RAMN, 2010. No. 3 (73). (in Russian)

29. Laget S, Broncy L, Hormigos K, Dhingra DM, BenMohamed F, Capiod T, et al. Technical Insights into Highly Sensitive Isolation and Molecular Characterization of Fixed and Live Circulating Tumor Cells for Early Detection of Tumor Invasion. PLOS ONE, 2017, 12 (1): e0169427. https://doi.org/10.1371/journal.pone.0169427

30. Ushakova G.O. Modern methods of clinical diagnostics. Guidelines. Dnipropetrovsk: DNU. 2003. $52 \mathrm{p}$.

31. Zlepko S.M., Chernyshova T.A., Timchik S.V., Krivonosov V.E., Zlepko O.S. Information system (IS) for receiving and processing microscopic images of circulating tumor cells (CTC). Achievements of clinical and experimental medicine, 2017, № 4. P. 39-46. (in Ukranian)

32. Azarhov O.Yu., Zlepko S.M., Timchik S.V., Chernyshova T.A.,. Danilkov S.O Methods and tools for computer analysis of microscopic images of circulating tumor cells. Bulletin of scientific researches. 2017. No. 4. P. 162-166. (in Ukranian)

33. Golovnya V.M., Zlepko S.M. The system of express diagnostics of formed blood elements. Measuring and computing engineering in technological processes. 2010, 2. P. 163-168. (in Ukranian) 
34. Lyadov V.K., Ledin E.V., Skrypnikova M.A. Cytological diagnostics of pancreatic adenocarcinoma by the method of isolating the size of circulating tumor cells from peripheral blood: a message from practice. Clinical Laboratory Diagnostics, 2017. No. 11. P. 31-39. (in Russian)

35. Kit O.I., Novikova I.A, Selutina O.N., Dontsov V.A., Chernikova E.N., Samaneyeva N.Yu., Nistratova O.V. Investigation of the level of the central ankylosing spondylitis in epithelial tumors of various localizations. International Journal of Applied and Fundamental Researches. 2018. No. 12-5. P.817-820. (in Russian)

\section{ЛИТЕРАТУРА}

Resieved 26.12.2018

1. Krivacic R.. Ladanyi A., Curry D., Hsieh H., Kuhn P., Bergsrud D., Kepros J. A rare-cell detector for cancer. Proceedings of the National Academy of Sciences of the United States of America. 2004. V. 101, N 29. P. 10501-10504.

2. Harouaka R., Kang Z., Zheng S.Y., Cao L. Circulating tumor cells: advances in isolation and analysis, and challenges for clinical applications. Pharmacol Ther. 2014. Vol. 141. P. 209-221.

3. Tewes M., Aktas B., Welt A., Mueller S., Hauch S., Kimmig R., Kasimir-Bauer S. Molecular profiling and predictive value of circulating tumor cells in patients with metastatic breast cancer: an option for monitoring response to breast cancer related therapies. Breast cancer research and treatment. 2009. Vol. 115, N 3. P. 581-590.

4. Danila D.C., Heller G., Gignac G.A. et al. Circulating tumor cell number and prognosis in progressive castration-resistant prostate cancer. Clin Cancer Res. 2007. Vol. 13(23). P. 7053-7058.

5. Krivacic R.. Ladanyi A., Curry D., Hsieh H., Kuhn P., Bergsrud D., Kepros J. A rarecell detector for cancer. Proceedings of the National Academy of Sciences of the United States of America. 2004. Vol. 101, N 29. P. 10501-10504.

6. Ntouroupi T., Ashraf S., McGregor S., Turney B., Seppo A., Kim Y., Wang X. Detection of circulating tumour cells in peripheral blood with an automated scanning fluorescence microscope. British journal of cancer. 2008. Vol. 99, N 5. P. 789-795.

7. Bauer K., de la Torre-Bueno J., Diel I., Hawes D., Decker W., Priddy C., Bossy B. Reliable and sensitive analysis of occult bone marrow metastases using automated cellular imaging. Clinical cancer research: an official journal of the American Association for Cancer Research. 2000. Vol. 6, N 9. P. 3552-3559.

8. Kagan M., Howard D., Bendele T., Mayes J., Silvia J., Repollet M., Doyle J. A Sample Preparation and Analysis System for Identification of Circulating Tumor Cells. Journal of Clinical Ligand Assay. 2002. Vol. 25, N 1. P. 104-110.

9. Andreopoulou E., Yang L.-Y., Rangel K., Reuben J., Hsu L., Krishnamurthy S., Valero V. Comparison of assay methods for detection of circulating tumor cells in metastatic breast cancer: AdnaGen AdnaTest BreastCancer Select. Detect ${ }^{\mathrm{TM}}$ versus Yeridex CellSearch $^{\mathrm{TM}}$ system. Int. journal of cancer. 2012. Vol. 130, N 7. P. 1590-1597.

10 Nezos A., Pissimisis N., Lembessis P., Sourla A., Dimopoulos P., Dimopoulos T., Tzelepis K. Detection of circulating tumor cells in bladder cancer patients. Cancer treatment reviews. 2009. V. 35, N 3. P. 272-279.

11. Tewes M., Aktas B., Welt A., Mueller S., Hauch S., Kimmig R., Kasimir-Bauer S. Molecular profiling and predictive value of circulating tumor cells in patients with metastatic breast cancer: an option for monitoring response to breast cancer related therapies. Breast cancer research and treatment. 2009. V. 115, N 3. P. 581-590.

12. Ignatiadis M, Lee M, Jeffrey SS. Circulating Tumor Cells and Circulating Tumor DNA: Challenges and Opportunities on the Path to Clinical Utility. Clin Cancer Res. 2015. No 21(21) P. 4786-800.

13. Alix-Panabieres $\mathrm{C}$, Pantel $\mathrm{K}$. Technologies for detection of circulating tumor cells: facts and vision. Lab Chip. 2014. No 14(1) P. 57-62.

14. Ferreira M.M, Ramani V.C, Jeffrey S.S. Circulating tumor cell technologies. Mol Oncol. 2016. 10(3) P. 374-94.

15. Gertler R., Rosenberg R., Fuehrer K., Dahm M., Nekarda H., Siewert J. Detection of circulating tumor cells in blood using an optimized density gradient centrifugation. 
Recent results in cancer research. Fortschritte der Krebsforschung. Progres dans les recherches sur le cancer. 2003. Vol. 162. P. 149-155.

16. Tan S., Yobas L., Lee G., Ong C, Lira C. Microdevice for the isolation and enumeration of cancer cells from blood. Biomedical microdevices. 2009. V. 11, N 4. P. 883-892.

17. Tan S., Yobas L., Lee G., Ong C, Lira C. Microdevice for the isolation and enumeration of cancer cells from blood. Biomedical microdevices. 2009. V. 11, N 4. P. 883-892.

18. А.А.Ковалев, Т.В. Грудинская, Т.П. Кузнецов, К.А. Ковалев. Гетерогенность циркулирующих опухолевых клеток. Онкология. 2012. Т.4. №2. С.126-129.

19. Павлов С.В., Кожем'яко В.П., Бурденюк I.I. Рамі Ребхі Хамді. Оптико-електронні технології аналізу біомедичних зображень. Вінниця: ВНТУ, 2011. $166 \mathrm{c.}$

20. Непомнящая Е.И., Кит О.И., Нистратова О.В., Новикова И.А. и др.. Циркулирующие опухолевые клетки и некоторые морфо-иммуно-гистохимические показатели при колоректальном раке. Современные проблемы науки и образования. 2016 . №2.

21. G. Vona, C. Béroud, A. Benachi, A. Quenette, J.P. Bonnefont, Y. Dumez, B. Lacour, P. Paterlini-Bréchot. Enrichment and genetic analyses of fetal cells circulating in the maternal blood by the ISET technique and single cell microdissection: a non-invasive tool for early prenatal diagnosis. Am. J. Pathol. 2002. No 160. P. 51-58.

22. Исмаилова Г. Laget S., Paterlini-Brechot P. Диагностика циркулирующих опухолевых клеток с помощью технологии ISET и их молекулярная характеристика для жидкостной биопсии. https://cyberleninka.ru/article/n/diagnostika-tsirkuliruyuschihopuholevyh-kletok-s-pomoschyu-tehnologii-iset-i-ih-molekulyarnaya-harakteristikadlya-zhidkostnoy.

23. Ледов В.К., Скринникова М.А., Попова О.П. Выделение циркулирующих опухолевых клеток методом «изоляции по размеру» (ISET) (обзор). Вопр. Онкологи. 2014. №60(5). C.548-552.

24. Байченко А.К., Шаймардинова Г. М., Попова Н.В., Жусинова Б.Т., Исмаилова Г.Н. Циркулирующие раковые клетки : молекулярная характеристика и мониторинг лечения рака. Клиническая медичина Казахстана. 2013. Vol.4. №30.

25. Волченко Н.Н. Цитологическая диагностика опухолей молочной железы. Маммология, 2006, №1, С. 35-39.

26. Paterlini-Bréchot $\mathrm{P}$, Benali-Furet NL. Circulating tumor cells (CTC) detection : Clinical impact and future directions. Cancer Letter. 2007. No 253. P. 180-204.

27. Д.А.Зубцов, Ж.И. Зубцова, А.В. Лавров, Е.В. Легченко и др. Циркулирующие опухолевые клетки (ЦОК) при раке молочной железы: прогностическая значимость и методы выделения. Труды МФТИ. 2012. Том 4. №3. С. 18-26.

28. А.А. Чимитов, Н.В.Рязанцева, Г.Ц.Дамбаев, В.Е.Хитрихеев и др. Фильтрация венозной крови болных с целью цитологической диагностики злокачественных новообразований. Бюллетень ВСНИ СО РАМН, 2010. №3(73).

29. Laget S, Broncy L, Hormigos K, Dhingra DM, BenMohamed F, Capiod T, et al. Technical Insights into Highly Sensitive Isolation and Molecular Characterization of Fixed and Live Circulating Tumor Cells for Early Detection of Tumor Invasion. PLOS ONE, 2017, 12 (1): e0169427. https://doi.org/10.1371/journal.pone.0169427

30. Ушакова Г.О. Сучасні методи клінічної діагностики. Методичні рекомендації. Дніпропетровськ: ДНУ. 2003. 52 с.

31. Злепко С.М., Чернишова Т.А., Тимчик С.В., Кривоносов В.С., Злепко О.С. Інформаційна система (ШС) для отримання та оброблення мікроскопічних зображень циркулюючих пухлинних клітин (ЦПК). Здобутки клінічної $і$ експериментальної медицини, 2017, № 4, С. 39-46.

32. О.Ю. Азархов, С.М. Злепко, С.В. Тимчик, Т.А. Чернишова, С.О. Данилков. Методи і засоби для комп'ютерного аналізу мікроскопічних зображень циркулюючих пухлинних клітин. Вісник наукових досліджень. 2017. № 4. С. 162-166.

33. Головня В.М., Злепко С.М. Система експрес-діагностики формених елементів крові. Вимірювальна та обчислювальна техніка в технологічних прочесах. 2010, «2, с. 163-168.

34. Лядов В.К., Ледин Е.В., Скрипникова М.А. Цитологическая диагностика аденокарциномы поджелудочной железы методом выделения по размеру циркулирующих 
опухолевых клеток из периферической крови: сообщение из практики. Клиническая лабораторная диагностика, 2017. №11. С.31-39.

35. Кит О.И., Новикова И.А., Селютина О.Н., Донцов В.А., Черникова Е.Н., Саманеева Н.Ю., Нистратова О.В. Исследование уровня ЦОК при эпителиальных опухолях различных локализаций. Международный журнал прикладных и фундаментальных исследований. 2018. №12-5. С.817-820.

Получено 26.12.2018

Чернишова Т.А., лікар,

e-mail: tetyana.che@gmail.com

Авіаційний медичний центр

Національного авіаційного університету,

просп. Комарова, 1, 03058, Україна

\section{КРИТЕРІЇ ТА МЕТОД ВИЯВЛЕННЯ ЦИРКУЛЮЮЧИХ ПУХЛИННИХ КЛІТИН}

Вступ. Сучасні досягнення науки і техніки суттєво розширили можливості розпізнавання злоякісних новоутворень. Наявність великої групи методів виявлення і виділення циркулюючих пухлинних клітин (ЦПК) явно вказує на інтерес, який проявляють дослідники до ЦПК.

Мета роботи - формування комплексу критеріїв оцінювання злоякісності пухлини та удосконалення методу виявлення циркулюючих пухлинних клітин в крові людини.

Результати. Запропонований метод визначення циркулюючих пухлинних клітин, який є удосконаленням технології ISET, об'єднує два етапи. На першому етапі здійснюється виділення ЦПК з удосконаленням за рахунок встановлення двох додаткових полікарбонатних фільтрів 3 порами діаметром 5 і 3 мкм та забезпеченні режиму $100 \%$ герметизації камери з гемолізатом і постійного тиску протягом всього процесу фільтрації. На другому етапі за використання сформованого комплексу критеріїв здійснюється визначення ступеня злоякісності виділених клітин. Використання розробленого методу у автоматизованій системі аналізу цифрових мікроскопічних зображень циркулюючих пухлинних клітин забезпечує визначення і розрахунок характерних ознак для віднесення об'єкта до певного класу злоякісності та формування бази даних сканованих зображень 3 наявними клітинами або їх утвореннями, а також остаточну перевірку результатів оцінювання злоякісності пухлини за шаблонами-масками ЦПК і доброякісної пухлинної клітини.

Висновки. Застосування запропонованого методу визначення циркулюючих пухлинних клітин уможливлює виявлення цих клітин меншого розміру, ніж у разі використання традиційних методів, а також забезпечення їх цілісності та неушкодженості.

Ключові слова: ииркулюючі пухлинні клітини, критерії оцінювання злоякісності пухлин, метод визначення циркулюючих пухлинних клітин у крові людини. 
Чернышева T.A., врач,

e-mail: tetyana.che@gmail.com

Авиационный медицинский центр

Национального авиационного университета,

просп. Комарова,1, Киев, 03058, Украина

\section{КРИТЕРИИ И МЕТОД ВЫЯВЛЕНИЯ \\ ЦИРКУЛИРУЮЩИХ ОПУХОЛЕВЫХ КЛЕТОК}

Предложенный метод определения циркулирующих опухолевых клеток, который является усовершенствованием технологии ISET, объединяет два этапа. На первом этапе осуществляется выделение ЦОК с совершенствованием за счет установки двух дополнительных поликарбонатных фильтров с порами диаметром 5 и 3 мкм и обеспечении режима $100 \%$ герметизации камеры гемолизации и постоянного давления в течение всего процесса фильтрации. На втором этапе при использовании сформированного комплекса критериев осуществляется определение степени злокачественности выделенных клеток. Использование разработанного метода в автоматизированной системе анализа цифровых микроскопических изображений циркулирующих опухолевых клеток обеспечивает определение и расчет характерных признаков для отнесения объекта к определенному классу злокачественности и формирования базы данных сканированных изображений с занесением имеющихся клеток или их образований, а также окончательную проверку результатов оценки злокачественности опухоли по шаблонаммаскам ЦОК и доброкачественной опухолевой клетки.

Ключевые слова: циркулирующие опухолевые клетки, критерии оценки злокачественности опухолей, метод определения циркулирующих опухолевых клеток в крови человека. 